REGULAR ARTICLE

\title{
GENDER PERSPECTIVES OF THE DETERMINANTS OF CLIMATE ADAPTATION: THE CASE OF LIVELIHOOD DIVERSIFICATION IN NORTHERN GHANA
}

\author{
William ADZAWLA ${ }^{1 *}$, Abou $K A N E^{2}$
}

\author{
Address: \\ ${ }^{1}$ University of Cheikh Anta Diop, West African Science Service Centre on Climate Change and Adapted Land Use \\ (WASCAL), Climate Change Economics, BP 5683, Dakar, Senegal. \\ ${ }^{2}$ University of Cheikh Anta Diop (UCAD), Faculté des Sciences économiques et de Gestion (FASEG), BP 5005, Dakar- \\ Fann, Senegal \\ *Corresponding author: adzawla.w@edu.wascal.org
}

\begin{abstract}
Livelihood diversification is one of the essential climate adaptation strategies with positive outcomes on household's standard of living. Therefore, the identification of factors that are necessary for livelihood diversification are crucial. Within a gender perspective, this study analysed the determinants of livelihood diversification among farmers in the northern regions of Ghana. A mul tistage sampling procedure was used to select 619 farmers and the data was analysed using multivariate probit regression for the pooled and separately for the gender groups. The livelihood diversification strategies identified were crop diversification, crop-livestock diversification, crop-trade diversification, crop-agroprocessing diversification and crop-professional/skilled employment. The multivariate probit results showed that socioeconomic, institutional factors, climate factors, and household assets have significant influence on each diversification strategy. The assumption of gender difference in the factors that influences livelihood diversification is appropriate since some factors which influence specific livelihood diversification for females do not have significant effect on males. Improving the financial assets, social and human assets of farmers is important to enhance the diversification of farmers. There is also the need to improve awareness of farmers on climate shocks in order to enhance diversification decisions.
\end{abstract}

Keywords: Climate adaptation, Gender, Livelihood diversification, Multivariate probit, Northern Ghana JEL: C31, C35, J22, Q12

\section{INTRODUCTION}

Climate change and its associated impacts have become a global concern. The effect is not universally distributed as some groups or geographical areas are more impacted than others. One of the major group with differential climate impact is gender groups. Generally, two options are available for responding to climate change and these are mitigation and adaptation. Although both strategies are crucial in the fight against climate change in the short and long term, adaptation has become a localised strategy that is implemented at the individual or group levels. Adaption has also become more crucial to provide short term gains to households and to recover from environmental shocks such as floods and droughts. Adaptation is crucial because it is mostly stimulated by climate variability such as floods and droughts other than climate change (Berrang-Ford $\boldsymbol{e t}$ al., 2011). Mostly, these strategies are adopted as anticipatory, reactive or proactive measures. Among others, the primary goal of adaptation is to reduce or spread risks and secure income or resources (BerrangFord et al., 2011).

Adaptation is the adoption of specific strategies in order to secure livelihoods by using resources more efficiently. Adaptation occurs by reducing exposure to a known threat (Wilby and Dessai, 2010), in this case, climate change and variability. It is a localised concept as the strategies to adopt depends on the available opportunities in terms of the presence of the strategy and the availability of resources for its adoption. Efforts towards sustainable agriculture requires that actions and inactions of farmers and other actors in the agriculture sector contribute positively to ending hunger and poverty and ensuring a carbon-neutral world. From Downing (1993), the ultimate effect of climate change depends largely on the adaptive responses. As such, adaptation to climate change is gaining more prominence. FAO (2016) argued that in the absence of "adaptation to climate change, it will not be possible to achieve food security for all and eradicate hunger, malnutrition and poverty". An important characteristic of adaptation is that the costs of action is a fraction of non-adaptation or inaction. Wossen et al. (2017) argued that with smooth adaptation, climate change impacts can be minimised substantially and adverse effects of food security could be altered.

Generally, the recent literature on adaptation can be classified as following a bottom-up or a top-down approach (scenario-led) (Wilby and Dessai, 2010). Topdown studies examined adaptation in a global perspective and therefore generalised conclusion on the nature and effects of adaptation. Contrarily, bottom-up studies examined adaptation in a local perspective. In bottom-up, the analysis commence with the factors and conditions that enable successful coping with climate related threats at the 
individual, household or community level (Wilby and Dessai, 2010). Although both provide insights into the need and potential effects of adaptation, there is the need to give much attention to the bottom-up approach in order to identify localised strategies required to address the environmental changes. Yaro and Hesselberg (2016) noted that understanding adaptation in West Africa is essential since developmental challenges are knotted with climate. Also, a detailed analysis of adaptation helps to identify which interventions or diversification strategies are more helpful and to whom it is most helpful (Yaro et al., 2016). Economic views and analysis of adaptation are moving from market solutions and cost-benefit to include inequalities and behavioural biases (Wong et al., 2014). This is because of class differences in adaptation and returns from adaptation. For instance in a study by Jost $\boldsymbol{e} t$ al. (2015), male farmers in Ghana mentioned female farmers as primary decision makers in the adoption of new crop varieties since they are responsible for household food supply. On the other hand, the female farmers described their male counterparts as the primary adopters since the males aim mainly at maximising their profits. Similarly, due to control over resources, male farmers adopts strategies such as fertiliser application while female farmers diversify into non-farm jobs (Riede $\boldsymbol{e t}$ al., 2016).

Although adoption of sustainable agricultural practices could improve yields and income, the increases in income cannot be sustainable under the uncertainty in climatic conditions, hence the need for diversification to further enhance farmers' resilience (FAO, 2016b). Thus, one of the localised adaptation strategies is livelihood diversification. Farmers' understanding of climate variations has preconditioned them to diversify into nonfarm and on-farm activities, primarily, to reduce the risks from agriculture and to maintain or improve household's livelihood outcomes. In a focus group discussion in Kanshegu community of Ghana, men's group indicated that 'farming is no longer good so we need to diversify our livelihood' while the female's group indicated that 'every woman now wants to engage in more than one activity as a way of achieving livelihood security' (Yaro et al., 2016, pp.71). To maximise the expected benefits from these diversification strategies, it is imperative to understand the factors that influence the adoption of each livelihood strategy within a gender perspective. This would help identify the factors that are needed to be promoted to enhance livelihood diversification among males and females. Therefore, this study is designed to analyse the determinants of the adoption of various livelihood diversification among farming households.

Review of empirical studies on livelihood diversification Ofolsha and Mansingh (2015) analysed the determinants of livelihood diversification among female headed households of Ethiopia using a multinomial logit. This study showed that farm and livestock based diversification are the major diversification strategies adopted by farmers. However, there are other diversifications into non-farm activities such as petty trading and handcrafts. The factors that had significant influence livelihood diversification of the households were dependency, irrigation water, total livestock ownership and land area cultivated. The authors concluded that female headed households engage in diversification in order to offset low resource endow ment challenges. The study of Debele and Desta (2016) found that the major diversification strategy of pastoralist were crop production, petty trades, firewood and charcoal production while livestock contributes more to household income. The factors that significant influenced the adoption of the various diversification strategies were the age of the household head, education level of household head, size of livestock holding, distance to market and access to rural credit. The authors argued for an enhanced provision of credit facilities and the development road facilities. Contrary to most studies on the role of credit in diversification, Simtowe (2010) found that access to credit reduces the probability of diversifying from agriculture.

Owitti (2015) analysed the gender differences in livelihood diversification on the premise that there is less research effort on the analysis of gender-based inequalities. In addition to on-farm diversification, both men and women engages in off and non-farm livelihood diversification strate gies to mitigate food stress in periods of shock. The study found a significant power imbalance between men and women. Women than men were found to engage in unpaid jobs, with high domestic work burden and constraints of livelihood diversification such as socioeconomic and sociocultural constraints. In analysing livelihood diversification within a gender perspective in northern Ghana, Zakaria et al. (2015) found that although livelihood diversification is common among gender groups, it is high for males than females. In a similar study, Javed et al. (2015) found that non-poor, female headed households with larger family sizes have high diversity than the male heads with smaller household sizes. This is similar to the finding of Simtowe (2010) where female heads have high probability of diversifying into non-farm activities. Albore (2018) argued that diversification is a norm in most economies since farm income is insufficient for a decent living. In a review and consistent with many others, Albore (2018) classified the determinants of livelihood diversification into push and pull factors. The author showed that push factors dominant in high risk and low potential agricultural areas, and this includes climatic conditions, land constraints and market constraints. On the other hand, pull factors are opportunity-led conditions where there are expanded range of high return livelihood activities in addition to farming. Albore (2018) outlined that these factors can be social, institutional, economic or demographic. Specifically, Gebreyesus (2016) found in their study that the livelihood diversification is significantly explained by the age, education, number of non-farm activities, market distance, number of livestock, credit cost and farm size of the respondents. Similarly, Kassie et al. (2017) found age, gender, membership of farmer cooperation, education and distance to the proximate market to influence livelihood diversification in different directions. The literature on the determinants of livelihood diversification in northern regions of Ghana appears to be absent, hence the need for this study to address this literature gap. 


\section{DATA AND METHODS}

\section{Study area}

The study was conducted in the three northern regions of Ghana (Upper East, Upper West and Northern regions). The area is located within latitude $80-110 \mathrm{~N}$ and longitude 00-30W. As at the last general housing and population census in 2010, the three regions had a total population of $4,228,116$, representing $17.1 \%$ of Ghana's total population. The average population growth of the region is $2.0 \%$, lower than the national population growth rate of $2.5 \%$ (GSS, 2012).

Unlike in the southern and middle belts of Ghana, the northern regions experience a unimodal rainfall. The rainfall in the regions range between $916 \mathrm{~mm}$ to $1,169 \mathrm{~mm}$. the unimodal rainfall limits crop production to a single season in the while year. Therefore, farmers have lots of idle periods for other livelihood activities. The soil $\mathrm{pH}$ is within 4.5-6.8 with about $0.5-2.5 \%$ organic matter (MoFA, 2013). Agriculture is the main economic activity, employing $71.9 \%$ of the economically active group; the three northern regions has the highest proportion of agricultural households and far above the national average of $45.8 \%$ (GSS, 2014). Poverty levels, inequality and rural population is higher in the three northern regions than other regions of Ghana.

\section{Sampling design}

The study population is maize farming households who cultivated maize in the 2016 cropping season and located in the three northern regions. The study lack data on the actual number of maize farming households in the targeted regions. Therefore, the sample was determined using single population proportion approach (Cochran, 1977; Tessema, 2017) which rely on information on the proportion of a particular interest in the total population. In this study, the interest is the proportion of farmers in the entire active workforce which is $71.9 \%$ (GSS, 2012). The single population proportion approach is given as Eq. 1 (Cochran, 1977).

$n=\frac{Z^{2} * p(1-p)}{\varepsilon^{2}}$

Where: $z$ is the $z$ score, $\varepsilon$ is the margin of error, $\hat{p}$ is the population proportion. Given a population proportion as approximately $72 \%(0.72)$; a $95 \%$ confidence level that the estimated sample reflects the true sample if the actual population was known, thus a $\mathrm{Z}$ score of 1.96; and a $5 \%$ margin of error, the sample was obtained as Eq. 2 .

$n=\frac{1.96^{2} * 0.72(1-0.72)}{0.05^{2}}=307$

Therefore, a minimum of 307 farm households must be selected for the study. However, this was adjusted to 432 farm households.

In selecting the respondents, a multistage sampling procedure was used. Among the ten admi nistrative regions of Ghana, the three northern regions were selected due to their high vulnerability to climate change, high reliance on agriculture and high poverty levels. Again, maize farmers were purposively selected because it is the number one crop cultivated and consumed by almost all households. In the second stage, stratified sampling was used to put all districts the regions into three strata based on the prevalence of poverty in the region (GSS, 2015). Poverty was used as the basis for stratification since it is one of the major livelihood outcomes. The strata were poor, middle and rich class districts. Simple random sampling was then used in selecting at least one (1) district from each stratum in each region. Also, using simple random sampling approach, three communities from each district were selected, given a total of 27 communities from the three regions. In the final stage, stratified sampling was used to put maize farmers from the selected communities into groups. Thus, the sample frame was categorised into two as female and male household heads. From the 2010 population census (GSS, 2012), 23\% of the household heads in the three northern regions are females while the remaining $77 \%$ are men. Therefore, using proportion allocations in stratified sampling, a total of 324 male and 108 female household heads were selected, respectively. Also, to account for intra-household gender differences in livelihood diversification, a wife of $57 \%$ of the sampled male household heads who had also cultivated maize on their own farms in the 2016 cropping season were selected. This gives a total of 187 female spouses. Therefore, the total sample becomes 619 farmers.

\section{Data type and data collection}

The study used cross sectional primary data which was collected using questionnaire. The questionnaire was designed through a comprehensive process with input from other scholars and policy makers. The questionnaire was administered by a minimum of four Research assistants in each region. The research assistants were selected based on their experience in questionnaire administration, fluency in English and local dialect. A training workshop was held for the Research assistants.

The literature provides that several livelihood diversification options are available for farmers. Therefore, farmers make decision on engaging in various livelihood activities based on their expected utilities and available resources. Since a farmer can engage in a number of livelihood strategies simultaneously, a multivariate probit was used to estimate the factors influencing farmer's decision under each option. The advantage of multivariate analysis is that it allows the estimation of household's choice of one or more livelihood activities simultaneously and also provides the opportunity to demonstrate the joint decision making processes (Rahman and Akter, 2014). Following Greene (2012), this is discussed below.

The multivariate probit is an extension of bivariate probit that is used in situations where there are two binary response variables. For instance, if we want to examine the factors influencing farmers' crop diversification and croplivestock diversification, the decision by a farmer on these two diversification systems are autonomous. Therefore, we model for the two options simultaneously using the bivariate probit model.

The bivariate probit model is given by (Greene, 2012) (Eq. 3). 
$y_{1}^{*}=X_{1}^{*} \beta_{1}+\varepsilon_{1}, \quad y_{1}=1$ if $y_{1}^{*}$

$>0$, and 0 if otherwise

$y_{2}^{*}=X_{2}^{*} \beta_{2}+\varepsilon_{2}, \quad y_{2}=1$ if $y_{2}^{*}>$

0 , and 0 if otherwise

Where $y s$ are the latent for the bivariate responses and $X s$ are the independent variables. From Equation 3;

$\left(\begin{array}{l}\varepsilon_{1} \\ \varepsilon_{2}\end{array} \mid X_{1}, X_{2}\right) \sim N\left[\begin{array}{ll}0 \\ 0\end{array}\left(\begin{array}{ll}1 & \rho \\ \rho & 1\end{array}\right)\right]$

This also means that;

$E\left[\varepsilon_{1} \mid X_{1}, X_{2}\right]=E\left[\varepsilon_{2} \mid X_{1}, X_{2}\right]=0$

$\operatorname{Var} E\left[\varepsilon_{1} \mid X_{1}, X_{2}\right]=\operatorname{Var} E\left[\varepsilon_{2} \mid X_{1}, X_{2}\right]=1$

$\operatorname{Cov}\left[\varepsilon_{1}, \varepsilon_{1} \mid X_{1}, X_{2}\right]=\rho$

Using maximum likelihood estimation, the bivariate normal cumulative distribution unction $(\mathrm{CDF})$ can be given as Eq. 5 .
$\operatorname{Prob}\left(X_{1}<x_{1}, X_{2}<x_{2}\right)=$

$\int_{\infty}^{x_{2}} \int_{\infty}^{x_{1}} \emptyset_{2}\left(z_{1}, z_{2}, \rho\right) d z_{1} d z_{2}=\Phi_{2}\left(x_{1}, x_{2}, \rho\right)$

Therefore, the density function would be given by Eq. 6 .

$\Phi_{2}\left(x_{1}, x_{2}, \rho\right)=\frac{e^{-(1 / 2)\left(x_{1}^{1}+x_{2}^{2}-2 \rho x_{1} x_{2}\right)}}{2 \pi\left(1-\rho^{2}\right)^{1 / 2}}$

To derive the log-likelihood, the following notations are used;

$q_{i 1}=2 y_{i 1}-1$

$q_{i 2}=2 y_{i 2}-1$

Thus, $q_{i j}=1$ if $y_{i j}-1$ and -1 if $q_{i 1}=y_{i j}=0$;. Now, let $z_{i j}=X_{i j}^{\prime} \beta_{j}, w_{i j}=q_{i j} z_{i j}$ and $\rho_{i^{*}}=q_{i 1} q_{i 2} \rho$.

Where: the subscript 2 indicates a bivariate normal distribution of the density $\emptyset_{2}$ and $\Phi_{2}$. The probabilities that enters the likelihood functions are;

Table 1: Definition of the variables and their expected signs.

\begin{tabular}{|c|c|c|}
\hline Variable & Definition & Apriori \\
\hline Gender & Dummy: 1 if male, 0 if female & + \\
\hline Age & Total number of years of a famer from birth & - \\
\hline Adults & Number of household members with age 18 and above & + \\
\hline Home keeping & Number of hours spent on domestic activities & - \\
\hline Experience & Total number of years in farming & + \\
\hline Extension & Dummy: 1 if a farmer had access and 0 if otherwise. & + \\
\hline Contract farming & Dummy: 1 if a farmer engaged in contract farming and 0 if otherwise. & + \\
\hline Training & Dummy: 1 if a farmer had agricultural related training and 0 if otherwise. & + \\
\hline FBO & Dummy: 1 if a famer belongs to an FBO and 0 if not & + \\
\hline Credit access & Dummy: 1 if a farmer had access to agricultural credit and 0 if otherwise. & + \\
\hline Windstorm & $\begin{array}{l}\text { Dummy: } 1 \text { if experience a windstorm that affects properties within the } \\
\text { past } 3 \text { years and } 0 \text { if otherwise. }\end{array}$ & + \\
\hline Flood & $\begin{array}{l}\text { Dummy: } 1 \text { if a farmer experienced flooding within the past } 5 \text { years and } \\
0 \text { if otherwise. }\end{array}$ & + \\
\hline Drought & $\begin{array}{l}\text { Dummy: } 1 \text { if a farmer experienced drought within the past } 3 \text { years and } 0 \\
\text { if not }\end{array}$ & + \\
\hline Forest fires & $\begin{array}{l}\text { Dummy: } 1 \text { if a farmer experienced forest fire within the past } 3 \text { years and } \\
0 \text { if not }\end{array}$ & + \\
\hline Climate information & Dummy: 1 if a farmer had climate information and 0 if not & + \\
\hline CCV Perception & $\begin{array}{l}\text { Dummy: } 1 \text { if a farmer perceives an increase in temperature and decrease } \\
\text { in rainfall simultaneously and } 0 \text { if not }\end{array}$ & + \\
\hline Financial asset & $\begin{array}{l}\text { Measured using access to credit. } 1 \text { if a famer had access to credit and } 0 \\
\text { if otherwise. }\end{array}$ & + \\
\hline Physical asset & $\begin{array}{l}\text { PCA weighted sum of physical assets (tractor, car, mobile phone, TV, } \\
\text { radio, bicycle, motorbike, sewing machine and electric cooker) of a } \\
\text { farmer }\end{array}$ & + \\
\hline Social asset & $\begin{array}{l}\text { PCA weighted sum of social assets (number of single sexed groups, } \\
\text { number of combined sex groups and conflict) of a farmer }\end{array}$ & + \\
\hline Human asset & $\begin{array}{l}\text { PCA weighted sum of human assets (household labour force, number of } \\
\text { days of causal labour provided in a month and education) of a farmer }\end{array}$ & + \\
\hline Technological asset & $\begin{array}{l}\text { PCA weighted sum of all technological assets (access to irrigation, } \\
\text { improved seeds and subsidised fertiliser) of a farmer }\end{array}$ & + \\
\hline Political asset & $\begin{array}{l}\text { PCA weighted sum of all political assets (leadership position, family } \\
\text { member involvement in active politics, membership of a political group) } \\
\text { of a farmer }\end{array}$ & + \\
\hline
\end{tabular}


$\operatorname{Prob}\left(Y_{1}=y_{i 1}, Y_{2}=y_{i 2} \mid X_{1}, X_{2}\right)=\Phi_{2}\left(w_{i 1}, w_{i 2}, \rho_{i^{*}}\right)$

Therefore the log-likelihood function (Eq. 7).

$\operatorname{InL}=\sum_{i=1}^{n} \operatorname{In} \Phi_{2}\left(w_{i 1}, w_{i 2}, \rho_{i^{*}}\right)$

Given the above information, the multivariate probit model can be extended as Eq. 8 .

$y_{m}^{*}=X_{m}^{*} \beta_{m}+\varepsilon_{m}, y_{m}=1$ if $y_{m}^{*}>0$,

and 0 if otherwise, $\mathrm{m}=1,2, \ldots, \mathrm{M}$

Where;

$E\left[\varepsilon_{m} \mid X_{m} \ldots X_{m}\right]=0$

$\operatorname{Var} E\left[\varepsilon_{m} \ldots \varepsilon_{m} \mid X_{m} \ldots . X_{m}\right]=1$

$\operatorname{Cov}\left[\varepsilon_{m} \ldots \varepsilon_{m} \mid X_{m} \ldots . X_{m}\right]=\rho_{j m}$

$\left(\varepsilon_{m} \ldots \varepsilon_{m}\right) \sim N_{m}(0, \mathrm{R})$

The log-likelihood function (Eq. 10).

$L_{m}=\Phi_{m}\left(q_{i 1} X_{i 1}^{*} \beta_{1}, \ldots, q_{i m} X_{i m}^{*} \beta_{m}, \mathrm{R}^{*}\right)$

Where $q_{i m}=2 y_{i m}-1$ and $\mathrm{R}^{*}{ }_{j m}=q_{i m} X_{i m}^{*} \rho_{j m}$ The empirical model estimated for livelihood diversification is given as Eq. 11 .

Livelihood diversification $=\beta_{0}+\beta_{1}$ Gender + $\beta_{2}$ Age $+\beta_{3}$ Adults $+\beta_{4}$ Homekeeping + $\beta_{5}$ Experience $+\beta_{6}$ Extensiion $+\beta_{7}$ Contract farming + $\beta_{8}$ Training $+\beta_{9}$ FBO $+\beta_{10}$ Credit access + $\beta_{11}$ Arable land $+\beta_{12}$ Windstorm $+\beta_{13}$ Flood + $\beta_{14}$ Drought $+\beta_{15}$ Forest fire +

$\beta_{16}$ Climate information $+\beta_{17}$ CCV perception +

$\beta_{18}$ Financial assets $+\beta_{19}$ Physical assets +

$\beta_{20}$ Social assets $+\beta_{21}$ Human assets +

$\beta_{22}$ Technological assets $+\beta_{23}$ Political assets

Table 1 provides the definition of variables and their expected signs.

\section{RESULTS AND DISCUSSION}

Distribution of livelihood diversification among farmers The distribution of livelihood diversification among the sampled respondents (Tab. 2) shows, that irrespective of the gender group, the majority of maize farmers engage in crop diversification and crop-livestock diversification. These were nonetheless higher for male heads than the female groups. However, more females (both female heads and female spouses) engage in other livelihood portfolios than male heads. This implies that while onfarm diversification is higher for males, non-farm diversification is higher for females.

\section{Model diagnosis}

From the result, the estimated Wald chi squares in all four models were statistically significant, implying that the estimated models were well fitted. The joint correlation tests in all the models were also significantly different from zero (Table 3). The significance of the joint correlation means the hypothesis that the adoption decision of livelihood diversification strategies is independent (zero correlation between the error terms) is rejected; hence, the estimation of the multivariate model is appropriate. Also, most of the paired correlation test between livelihood strategies were significant and positive or negative (Table 3 ). The positive correlation means that these livelihood diversification strategies are complementary with the negative correlation means that these strategies are substitutes. Generally, majority of the paired correlations were negative, suggesting a high substitutability of the diversification strategies. This was expected as engaging in these strategies require resource investment.

\section{Factors influencing the adoption of various livelihood diversification strategies}

In the following sections, the factors that influenced the adoption of the various livelihood diversification strategies are provided.

\section{Factors influencing crop diversification}

Crop diversification involves the cultivation of more than one crop either on the same plot or on separate plots. In this study, crop diversification is defined as the cultivation of any other staple crop in addition to maize. In diversification literature, crop diversification is one of the strategies that is highlighted to improve household food security and welfare, amidst climate change. For instance, Neudert et al. (2015) provides that households become wealthy with higher crop diversity while Birthal $\boldsymbol{e t}$ al. (2015) argued that crop diversification into high-valued crops can enhance household's livelihood outcomes such as food security and welfare. The factors that significantly determine households' decision into crop diversification are gender, age, extension, contract farming, windstorm, flood, climate information, financial assets, physical assets, social assets, human assets and technological assets (Tab.4).

Table 2: Level of engagement in various livelihood strategies

\begin{tabular}{lllllll}
\hline Livelihood strategy & \multicolumn{3}{c}{ Male heads } & \multicolumn{2}{c}{ Female heads } & \multicolumn{2}{c}{ Female spouses } \\
& Freq. & $\%$ & Freq. & $\%$ & Freq. & $\%$ \\
\hline Crop diversification & 288 & 88.89 & 85 & 78.70 & 153 & 81.82 \\
Animal rearing & 262 & 80.86 & 61 & 56.48 & 104 & 55.61 \\
Trading & 88 & 27.16 & 35 & 32.41 & 56 & 45.99 \\
Agro-processing & 92 & 28.40 & 48 & 44.44 & 54 & 28.88 \\
Professional/skilled employment & 77 & 23.77 & 30 & 27.78 & 60 & 32.09 \\
\hline
\end{tabular}


Table 3: Correlation matrix of error terms

\begin{tabular}{|c|c|c|c|c|c|}
\hline $\mathrm{X}$ & Sample category & $\mathrm{CD}$ & CLD & CTD & CAD \\
\hline \multirow[t]{4}{*}{ CLD } & Pooled & $0.142(0.076)^{*}$ & & & \\
\hline & Male heads & $0.035(0.139)$ & & & \\
\hline & Female heads & $0.235(0.194)$ & & & \\
\hline & Female spouses & $0.527(0.118) * * *$ & & & \\
\hline \multirow[t]{4}{*}{ CTD } & Pooled & $-0.200(0.075)^{* * *}$ & $-0.111(0.068)^{*}$ & & \\
\hline & Male heads & $-0.121(0.131)$ & $-0.027(0.109)$ & & \\
\hline & Female heads & $0.182(0.207)$ & $0.079(0.174)$ & & \\
\hline & Female spouses & $-0.54(0.116)^{* * *}$ & $-0.29(0.122)^{* *}$ & & \\
\hline \multirow[t]{4}{*}{ CAD } & Pooled & $0.069(0.077)$ & $-0.024(0.072)$ & $-0.058(0.068)$ & \\
\hline & Male heads & $-0.006(0.116)$ & $-0.157(0.08)^{* *}$ & $-0.077(0.096)$ & \\
\hline & Female heads & $-0.009(0.245)$ & $0.352(0.122)^{* *}$ & $-0.382\left(0.227^{*}\right)$ & \\
\hline & Female spouses & $0.363(0.137) * * *$ & $0.092(0.143)$ & $-0.124(0.135)$ & \\
\hline \multirow[t]{4}{*}{ CPD } & Pooled & $-0.003(0.081)$ & $-0.019(0.071)$ & $-0.19(0.0678) * * *$ & $-0.23(0.069)^{* * *}$ \\
\hline & Male heads & $-0.061(0.145)$ & $-0.059(0.117)$ & $-0.015(0.104)$ & $-0.37(0.108) * * *$ \\
\hline & Female heads & $-0.66(0.150) * * *$ & $-0.310(0.222)^{*}$ & $-0.331(0.259)$ & $0.033(0.259)$ \\
\hline & Female spouses & $0.059(0.132)$ & $0.219(0.133)^{*}$ & $-0.35(0.116) * * *$ & $0.024(0.126)$ \\
\hline \multirow[t]{4}{*}{ Chi sq. } & Pooled & $33.744 * * *$ & & & \\
\hline & Male heads & $24.278 * * *$ & & & \\
\hline & Female heads & $18.034 *$ & & & \\
\hline & Female spouses & $50.598 * * *$ & & & \\
\hline
\end{tabular}

Note: $* * * * *$ and $*$ indicates significant levels at $1 \%, 5 \%$ and $10 \%$, respectively; $\mathrm{CD}=\mathrm{On}$-farm (crop) diversification; CLD=CropLivestock diversification; $\mathrm{CTD}=\mathrm{Crop}-$ Trade diversification; $\mathrm{CAD}=\mathrm{Crop}$-Agro-processing diversification; $\mathrm{CPD}=\mathrm{Crop}-\mathrm{Prof} / \mathrm{Skilled}$ job diversification

Table 4: Factors influencing crop diversification

\begin{tabular}{|c|c|c|c|c|c|c|c|c|}
\hline \multirow[t]{2}{*}{ Variable } & \multicolumn{2}{|l|}{ Pooled } & \multicolumn{2}{|c|}{ Male heads } & \multicolumn{2}{|c|}{ Female heads } & \multicolumn{2}{|c|}{ Female spouses } \\
\hline & Coeff. & $\begin{array}{l}\text { Std. } \\
\text { Error }\end{array}$ & Coeff. & $\begin{array}{l}\text { Std. } \\
\text { Error }\end{array}$ & Coeff. & $\begin{array}{l}\text { Std. } \\
\text { Error }\end{array}$ & Coeff. & $\begin{array}{l}\text { Std. } \\
\text { Error }\end{array}$ \\
\hline Gender & $0.373^{\mathbf{b}}$ & 0.162 & & & & & & \\
\hline Age & $-0.015^{b}$ & 0.007 & $-0.033^{\mathrm{a}}$ & 0.012 & -0.036 & 0.029 & 0.0001 & 0.017 \\
\hline Home keeping & 0.049 & 0.053 & -0.025 & 0.095 & -0.020 & 0.144 & 0.104 & 0.105 \\
\hline Experience & 0.008 & 0.007 & 0.016 & 0.010 & 0.019 & 0.019 & 0.013 & 0.016 \\
\hline Extension & $-0.364^{b}$ & 0.156 & $-0.871^{a}$ & 0.249 & -0.219 & 0.737 & 0.457 & 0.323 \\
\hline Contract farming & $0.616^{\mathrm{a}}$ & 0.212 & $0.923^{\mathbf{b}}$ & 0.399 & $2.811^{\mathrm{b}}$ & 1.363 & 0.360 & 0.337 \\
\hline Training & 0.195 & 0.158 & 0.251 & 0.255 & 0.490 & 0.573 & 0.050 & 0.300 \\
\hline Adults & 0.018 & 0.022 & 0.019 & 0.038 & 0.011 & 0.080 & 0.010 & 0.040 \\
\hline Windstorm & -0.133 & 0.165 & 0.217 & 0.271 & $-1.00^{c}$ & 0.541 & $-0.35^{c}$ & 0.356 \\
\hline Flood & -0.071 & 0.159 & $-0.639^{b}$ & 0.276 & $1.254^{\mathbf{b}}$ & 0.629 & 0.403 & 0.320 \\
\hline Drought & 0.099 & 0.154 & 0.141 & 0.242 & 0.729 & 0.485 & -0.294 & 0.301 \\
\hline Climate info. & $-0.268^{c}$ & 0.149 & -0.131 & 0.245 & 0.413 & 0.452 & $-0.68^{\mathbf{b}}$ & 0.281 \\
\hline Forest fires & 0.012 & 0.059 & 0.071 & 0.099 & 0.002 & 0.157 & 0.021 & 0.126 \\
\hline $\mathrm{CCV}$ perception & 0.087 & 0.158 & 0.255 & 0.260 & 0.196 & 0.473 & -0.439 & 0.322 \\
\hline Financial asset & $0.683^{a}$ & 0.183 & $0.647^{\mathbf{b}}$ & 0.288 & 0.778 & 0.822 & 0.273 & 0.330 \\
\hline Physical assets & 0.049 & 0.094 & 0.089 & 0.153 & 0.360 & 0.389 & $-0.24^{\mathbf{b}}$ & 0.107 \\
\hline Social assets & $0.031^{\mathbf{b}}$ & 0.016 & 0.030 & 0.038 & $1.074^{\mathrm{b}}$ & 0.454 & 0.020 & 0.022 \\
\hline Human assets & $0.068^{\mathrm{a}}$ & 0.023 & 0.049 & 0.037 & 0.156 & 0.101 & 0.066 & 0.042 \\
\hline Technology assets & $0.284^{\mathrm{c}}$ & 0.156 & 0.283 & 0.257 & $1.164^{\mathrm{c}}$ & 0.706 & $0.537^{\mathrm{c}}$ & 0.314 \\
\hline Political assets & 0.097 & 0.154 & 0.291 & 0.232 & -0.507 & 0.535 & -0.592 & 0.383 \\
\hline Constant & 0.801 & 0.384 & 1.915 & 0.626 & 0.202 & 1.236 & 1.047 & 0.797 \\
\hline
\end{tabular}

Note: ${ }^{\mathrm{a}, \mathrm{b}}$ and ${ }^{\mathrm{c}}$ indicate significant levels at $1 \%, 5 \%$ and $10 \%$, respectively

Gender had a positive effect on crop diversification and this means that male heads have a higher probability of engaging in crop diversification strategy than the females. This could be due to the vital role men play in providing food for the family. In most rural homes, men usually engage in the cultivation of multiple food crops to meet the food diversity needs of their families while women's crop productions are mainly to complement males' production. This is consistent with the findings of Abay et al. (2009). FAO (2016) and Adam and Zakaria (2015) also estimated that male farmers have higher crop diversification than females. Contrary, Rehima et al. (2013) estimated a negative effect of gender on crop diversification and argued that female heads may be more concerned about providing food for the family than the males. 
Age had a significant effect on crop diversification among the male heads and also for the pooled sample. The negative marginal effect means that the younger male heads or the younger farmers in general have a higher probability of cultivating an additional staple crop than the older farmers. In adoption studies, younger farmers are described as early adopters due to their innovativeness and their desire to try new things. Consistently, Shahbaz et al. (2017) and Asravor (2017) found a negative relationship between age and crop diversification and labour diversification, respectively. Jiao et al., (2017) argued that younger household heads are likely to engage in labour intensive diversification strategies than capital intensive strategies. Contrary, Asante et al. (2017) and Abay et al. (2009) found that the extent of crop diversification is higher for older farmers and argued that the older farmers are risk averse.

Extension access had a significant effect on crop diversification among male heads and the pooled sample. These effects were negative. Thus, male heads or farmers who had access to extension services have a lower probability of engaging in crop diversification. Although this is contrary to expectations, it is conceivable since extension services are often crop tailored. Thus, the services are provided to farmers cultivating a particular crop with no or minimal crop diversification promotion. Generally, FAO (2011) indicated a low access to extension services by women. Consistent with this study, Mesfin et al. (2011) and Abay et al. (2009) found a negative effect of extension on crop diversification. Mesfin et al. (2011) argued that, extension services aimed more at improving productivity and profitability which favour specialisation and neglects the role of crop diversification in risk reduction. The study of Asante $\boldsymbol{e t}$ al. (2017) however estimated a positive effect of extension on crop diversification decisions as well as the extent of diversification.

The effect of contract farming is positive in all models but significant for the pooled sample, male heads and female heads. This means that farmers, particularly, male and female heads who engaged in contract farming have a higher probability of diversifying crops. Contract farming provides opportunity for farmers to receive both physical inputs such as improved seeds and technological assistance from their partners.

The effect of flood on males' decision was negative but positive on females' decision and when pooled together, the effect was also negative. This was significant for male heads and the female heads. These effects mean that while male farmers who experienced flood within the past three years have less probability of engaging in crop diversification than those who did not experience flood, female farmers who experienced flood have higher probabilities of diversifying their crops. The study of Abay et al. (2009) revealed that there is a positive relationship between average rainfall and crop diversification. FAO (2016) also estimated that rainfall shocks have a negative effect on crop diversification in Niger.

Contrary to expectations and the findings of Ngigi $\boldsymbol{e t}$ al. (2017), farmers who received climate information have lesser probabilities of engaging in crop diversification.
One would expect that with climate information, the farmers would cultivate multiple crops other than only maize. However, the survey revealed that farmers that received climate information are able to identify the type of crop or maize variety to cultivate based on the information available to them. Therefore, they are likely to engage in crop specialization than crop diversification.

Financial asset (measured by access to credit) significantly influenced farmers' decision into crop diversification. Thus, male farmers and farmers as a whole, have a higher probability of engaging in crop diversification if they have access to in-cash or in-kind credit. The effect of credit on diversification can be explained through its effect on resource mobilization. The credit risk averse nature of females could explain the insignificant effect among the female spouses. Consistently, Adam and Zakaria (2015) also estimated no significant effect of credit on crop diversification by females. Physical assets had a negative significant on crop diversification decision of female spouses. On the other samples, the effect was positive but insignificant. The negative significant effect means that female spouses with higher physical assets have a higher probability of engaging in crop specialization than diversification. From Ngigi et al. (2017), the level of consumer durable assets was found to improve the probability of female spouses' adopting crop related climate smart technologies. Shahbaz et al. (2017) also found that households with tractor (a physical asset) ownership have higher crop diversification intensity. Social assets had a positive effect on both males and females as well as when gender blind is assumed. However, this effect is significant in only female heads and the pooled samples. While groups serve as a source of labour, providing assistance to each other (Ngigi et al., 2017), peaceful coexistence ensures that farmers have peace of mind to engage in their livelihood activities. This is consistent with the findings of Dube and Guveya (2016). There is a positive effect of human assets on crop diversification in all models but significant for only the pooled samples. Thus, with higher human assets, famers have higher probabilities of engaging in crop diversification. Studies such as Asravor (2017) and FAO (2016) also estimated a positive effect of education on crop diversification.

Technological assets had a positive effect on all models and also significant for all except male heads. This implies that the probability of engaging in crop diversification increases with the technological assets level. Empirically, Mesfin et al. (2011) found that farmers who own machineries such as water pumps have a high probability of crop diversification. However, Dube and Guveya (2016) found that farmers who engaged in irrigation farming have lower crop diversification index.

\section{Factors influencing mixed maize crop-animal diversification}

This section examined the factors influencing maize farmers' decision to engage in animal rearing as a livelihood strategy; thus, simultaneous maize-animal farming. Mixed crop-animal production system is an environmentally and economically sustainable production method where farmers engage in the production of crops 
and animals on the same piece of land or different pieces of land (Liebig et al., 2017; Nhemachena et al., 2014; Lemaire et al., 2013; Ryschawy et al., 2013; Tarawali et al., 2011). The system provides mutual benefits to both crops and animals (Thornton and Herrero, 2015; Valbuena et al., 2012; Herrero et al., 2010), cost effective (Asante $\boldsymbol{e t} \boldsymbol{a l} ., 2017$ ) and have less agricultural carbon footprints (Gil et al., 2016; Thornton and Herrero, 2015). Animals can easily be managed on farms in periods of climate shocks such as droughts (Chandra et al., 2017). Chandra et al. (2017) further argued that not only are livestock cheaper and less labourious, but also serve as an insurance for droughts and floods and a source of relief in times of hardship and crop failure. In this study, a number of socioeconomic, climate and asset factors had significant influence on both male and female farmers' probability of engaging in this farming system (Tab. 5).

Gender had a positive significant effect on diversification into animal production (Tab.5). This implies that the male heads have higher probability of engaging in this diversification portfolio than the females. This again justified the need for the segregation of the estimation based on the gender groups.

In all models, age had a negative effect on farmers' decision to engage in animal rearing. This is significant for all models except male heads' model. This means that younger farmers, particularly, younger female have a higher probability of engaging in mixed maize cropanimal farming system than the older farmers. Consistent with the findings of this study is the work of Jiao et al. (2017). Extension service had a negative significant effect on farmers' decision when the pooled sample is assumed. However, the effect is insignificant when gender samples are considered. The negative effect means that farmers who had access to extension services have a lesser probability of integrating animals into the crop farming systems than those who did not received extension service. Training had a mixed effect on crop-animal diversification as this was positive and significant for male heads but negative and significant for female heads. Thus, while male heads that had some form of training in crop production have a higher probability of engaging in mixed crop-animals farming, the reverse is the case for the female heads.

The number of adults in a household have a negative effect on animal rearing decision in all samples except that of the male heads. However, this effect is significant on only female spouses. This means that female spouses that have many adults in their households have lesser probability of engaging in mixed crop-animal farming system as a respond to climate change. In most agrarian households, adults provide readily available labour to each other, especially, the household heads.

Farmers, particularly male heads and their spouses, who experienced droughts over the past three years have a higher probability of engaging in integrated crop-animal farming. The reverse is true for the female heads, although insignificant. One reason for which animal rearing is a preferred adaptation strategy is the low dependence on rainfall for animal rearing. Therefore, it is conceivable that maize crop farmers who have experienced drought would engage in animal rearing since they can obtain water from sources such as pipes, boreholes or streams for the animals. However, flood had a negative significant effect on crop-animal diversification for the female spouses. Although insignificant, the positive effect of flood on diversification by the pooled sample, male heads and female heads are consistent with the researcher's apriori expectation. Generally, farmers who are able to observe or perceive the trend in climatic variables such as rainfall and temperature have a higher probability of rearing animals than those who perceive the trends in climate variables wrongly. The implication thereof is that those who have the right predictions are able to take precautionary measures and adapt to climate change accordingly. This is particularly significant for the pooled sample.

In all samples, financial assets have a positive effect on the decision to integrate animals into crop farming, but significant for only the pooled model. Thus, farmers or households with high financial assets have higher probabilities of engaging in mixed crop-animal farming than those with lesser financial asset. Financial assets provide a source of income for farmers and this could be a source of motivation towards the decision on animal rearing. Soltani et al. (2012) explained that access to financial capital encourage households to engage in lucrative activities that require less labour and land. Similarly, Asante et al. (2017) estimated a positive significant effect of credit on both the decision and extent of livestock diversification and also, a positive effect on the extent of crop-livestock integration. The effect of social assets on integrated crop-animal farming is positive in all models but significant for only the female headed households. In most farming communities, social asset is a major source of information, knowledge and labour. Therefore, with higher social assets, households can make the decision on rearing animals since they may get the social support for such activities. Human assets also have a positive effect on farmers' decision into integrated cropanimal farming. This is however significant for all samples except for male heads. This implies that farmers with high human assets have a higher probability of engaging in animal rearing. Consistently, Jiao et al. (2017), Gil et al. (2016) and Soltani et al. (2012) found a positive effect of education on diversification into livestock production. Contrary, Winters et al. (2009) found that, there is a negative relationship between education and livestock rearing in Ghana. The study also revealed that with increased technological assets, famers in general have an increasing probability of rearing animals in addition to crop production. This support the need for making technologies more available, accessible and easy to understand and use by the households.

\section{Factors influencing households' crop-trade diversification decision}

Trading involves buying and selling. It is one of the common livelihood strategies especially in informal economies such as rural agrarian communities. From the literature, trading is generally classified under non-farm diversification portfolios. The results for the determinants of crop-trade diversification (Tab. 6) shows the factors that had significant effect on the decision by farmers to engage in trading and crop farming simultaneously as a 
livelihood strategy in response to climate change and variability are discussed.

Expectedly, gender had a negative significant effect on trading decision by the farmers. Thus, females have a higher probability of engaging in trading activities than the males. Observation from Ghanaian economy suggests that females often engage in trading activities than males. This is contrary to the result of Mathenge and Tschirley (2015), where male heads have a higher probability of engaging in business and informal activities.

The higher the number of hours spent at home, the lesser the probability of engaging in trade activities (Tab. 6). This is specifically significant for female spouses and the pooled samples. Female spouses have much domestic activities to perform than the males, for instance, the provision of water, cooking and caring for children. Therefore, this effect is observed through the loss of time for engaging in trading activities in addition to farming. The number of adults present in a female headed household decreases the probability of engaging in croptrade diversification for the female heads. Contrary to this finding, Asmah (2011) found that the number of household members in various adult categories (15-59 years) have positive significant effects on non-farm diversification activities. Owusu et al. (2011) estimated that while household size generally leads to higher probability of non-farm employment, dependency ratio decreases the probability of engaging in the same activities. In general, experienced farmers have a lesser probability of engaging in crop-trade diversification than the less experienced farmers. This is significant for the pooled sample and the female heads. The study observed that, the experienced farmers have fair knowledge on climate change and are able to adopt crop production systems to minimise its impacts. Therefore, the probability of engaging in trading as a climate response strategy is lower for these experienced farmers. Access to extension services have a negative effect on the decision to engage in crop-trade diversification by both males and females. This effect is significant for all samples except male heads.

Windstorm has a mixed effect on household's decision to engage in crop-trade diversification. While male heads whose homes were affected by windstorm for the past three years have a lesser probability of engaging in crop-trade diversification, female heads that had similar windstorm impacts have a higher probability of engaging in crop-trade diversification. This effect was also positive for female spouse except that it is insignificant for these respondents. This demonstrates gender difference in factors that drives adaptation to climate change. The effect of forest fires on crop-trade diversification is significant and negative for female spouses. Thus, female spouses who experienced bushfires have a lesser probability of engaging in trading activities.

Assets that have significant effect on crop-trade diversification includes financial assets, physical assets, social assets and human assets. Financial and human assets have positive effects on female heads' decision to engage in crop-trade diversification; physical assets have a positive effect on male heads' decision to engage in crop-trade diversification; social assets have negative effect on female spouses' decision to engage in crop-trade diversification. The positive effects of financial, physical and human assets suggest that the probability of engaging in trading increases if the levels of these assets increase. This demonstrates the need to expand the asset level of these households in order to enhance their diversification into non-farm activities such as trading. Jiao et al. (2017) also estimated that households with high physical assets are more likely to engage in business activities, described as high remunerating livelihood strategies. Owusu $\boldsymbol{e t}$ al . (2011) also estimated a positive effect of financial asset on the decision to trade. In a more recent study also, Aziz et al. (2017) estimated a positive effect of access to formal credit on diversification into non-farm activities such as trading. Similarly, Osarfo et al. (2016) estimated that the ownership of physical assets such as truck and motorbikes improves the probability of engaging in non-farm livelihood activities such as petty trading. The negative significant effect of social assets on trading decision among the female heads could be as a result of low effectiveness of female heads' participation in social networks. This is contrary to the findings of Aziz et al (2017). The positive effect of social asset on trading is consistent with the findings of Ngigi et al. (2017) who established that there is a significant difference (favouring husbands) in farmer group participation although group members enjoy economies of scale.

\section{Factors influencing farmers' crop - agro-processing diversification decision}

This section involves the analysis of the factors that influence farmers' decisions to engage in diversification into agro-processing activities. A number of factors had significant effect on the farmers' decision (Table 7). These includes home keeping hours, experience, adults, extension access, training, drought, forest fires, climate information, financial assets, physical assets, social assets, human assets, technological and political assets. The specific effect of each factor is discussed below.

Although negative, the effect of gender on diversification into agro-processing is insignificant. Generally, female farmers and entrepreneurs are engaged in agro-processing than the males. This is consistent with the findings in Table 7 where more females than males engage in agro-processing.

The total number of hours spent on domestic activities had a positive significant effect on male headed households' and a negative effect on females' (significant for female spouses) decision into agro-processing. In most instances, men have much time to engage in off-farm activities than females since domestic works such as cooking are solely women activity in the northern Ghana. Matshe and Young (2004) argued that, the low level of females' participation in off-farm work is due to their time commitments at home and the general bias in labour time allocation. Relatedly, Kassie et al. (2017) elucidated that females perform activities such as cooking and child bearing/caring which are not considered as income generating activities but limits available time for engaging in diversification activities outside the farm. 
Table 5: Factors influencing crop-animal diversification

\begin{tabular}{|c|c|c|c|c|c|c|c|c|}
\hline \multirow[t]{2}{*}{ Variable } & \multirow{2}{*}{$\begin{array}{l}\text { Pooled } \\
\text { Coeff. }\end{array}$} & \multicolumn{3}{|c|}{ Male heads } & \multicolumn{2}{|c|}{ Female heads } & \multicolumn{2}{|c|}{ Female spouses } \\
\hline & & $\begin{array}{l}\text { Std. } \\
\text { Error }\end{array}$ & Coeff. & $\begin{array}{l}\text { Std. } \\
\text { Error }\end{array}$ & Coeff. & $\begin{array}{l}\text { Std. } \\
\text { Error }\end{array}$ & Coeff. & $\begin{array}{l}\text { Std. } \\
\text { Error }\end{array}$ \\
\hline Gender & 0.520 & 0.136 & & & & & & \\
\hline Age & -0.016 & 0.006 & -0.004 & 0.010 & $-0.035^{c}$ & 0.021 & -0.049 & 0.014 \\
\hline Home keeping & -0.045 & 0.044 & -0.024 & 0.081 & -0.125 & 0.132 & 0.005 & 0.079 \\
\hline Experience & 0.028 & 0.006 & 0.014 & 0.009 & $0.026^{c}$ & 0.015 & 0.059 & 0.014 \\
\hline Extension & $-0.235^{c}$ & 0.134 & -0.045 & 0.202 & -0.322 & 0.411 & -0.170 & 0.243 \\
\hline Contract farming & 0.020 & 0.156 & -0.064 & 0.245 & 1.606 & 0.643 & -0.288 & 0.269 \\
\hline Training & 0.079 & 0.132 & $0.407^{\mathrm{c}}$ & 0.208 & -0.912 & 0.424 & 0.164 & 0.253 \\
\hline Adults & -0.004 & 0.019 & 0.042 & 0.033 & -0.046 & 0.061 & $-0.058^{c}$ & 0.032 \\
\hline Windstorm & -0.091 & 0.139 & -0.291 & 0.215 & -0.157 & 0.379 & 0.329 & 0.301 \\
\hline Flood & 0.016 & 0.137 & 0.058 & 0.224 & 0.063 & 0.386 & $-0.450^{\mathrm{c}}$ & 0.249 \\
\hline Drought & $0.537^{\mathrm{a}}$ & 0.133 & $0.749^{\mathrm{a}}$ & 0.205 & -0.361 & 0.403 & 0.423 & 0.247 \\
\hline $\begin{array}{l}\text { Climate } \\
\text { information }\end{array}$ & -0.154 & 0.126 & $0.029^{\mathrm{c}}$ & 0.203 & -0.528 & 0.357 & -0.244 & 0.230 \\
\hline Forest fires & -0.010 & 0.049 & -0.006 & 0.081 & 0.154 & 0.134 & -0.049 & 0.092 \\
\hline CCV perception & $0.297^{\mathbf{b}}$ & 0.133 & 0.336 & 0.209 & 0.566 & 0.368 & 0.186 & 0.240 \\
\hline Financial asset & $0.279^{b}$ & 0.141 & 0.107 & 0.211 & 0.468 & 0.454 & 0.242 & 0.267 \\
\hline Physical assets & -0.005 & 0.084 & -0.160 & 0.133 & -0.164 & 0.203 & 0.280 & 0.184 \\
\hline Social assets & 0.017 & 0.012 & 0.034 & 0.027 & $0.109^{\mathrm{c}}$ & 0.068 & 0.001 & 0.019 \\
\hline Human assets & $0.034^{\mathrm{c}}$ & 0.019 & 0.034 & 0.031 & $0.220^{\mathbf{b}}$ & 0.086 & $0.059^{c}$ & 0.033 \\
\hline $\begin{array}{l}\text { Technological } \\
\text { assets }\end{array}$ & $0.299^{b}$ & 0.127 & 0.302 & 0.210 & 0.448 & 0.393 & 0.030 & 0.234 \\
\hline Political assets & 0.065 & 0.135 & 0.175 & 0.192 & 0.187 & 0.410 & 0.114 & 0.295 \\
\hline Constant & 0.036 & 0.324 & -0.220 & 0.503 & 2.018 & 1.087 & 1.252 & 0.631 \\
\hline
\end{tabular}

NOTE: ${ }^{\mathrm{a}, \mathrm{b}}$ and ${ }^{\mathrm{c}}$ indicate significant levels at $1 \%, 5 \%$ and $10 \%$, respectively

Table 6: Factors influencing households' crop-trade diversification

\begin{tabular}{|c|c|c|c|c|c|c|c|c|}
\hline \multirow[t]{2}{*}{ Variable } & \multirow{2}{*}{$\begin{array}{l}\text { Pooled } \\
\text { Coeff. }\end{array}$} & \multicolumn{3}{|c|}{ Male heads } & \multicolumn{2}{|c|}{ Female heads } & \multicolumn{2}{|c|}{ Female spouses } \\
\hline & & $\begin{array}{l}\text { Std. } \\
\text { Error }\end{array}$ & Coeff. & $\begin{array}{l}\text { Std. } \\
\text { Error }\end{array}$ & Coeff. & $\begin{array}{l}\text { Std. } \\
\text { Error }\end{array}$ & Coeff. & $\begin{array}{l}\text { Std. } \\
\text { Error }\end{array}$ \\
\hline Gender & $-0.453^{\mathrm{a}}$ & 0.127 & & & & & & \\
\hline Age & 0.007 & 0.006 & 0.007 & 0.009 & $0.085^{\mathrm{a}}$ & 0.026 & -0.003 & 0.012 \\
\hline Home keeping & $-0.112^{a}$ & 0.042 & -0.112 & 0.074 & -0.010 & 0.149 & $-0.187^{b}$ & 0.074 \\
\hline Experience & $-0.009^{c}$ & 0.005 & -0.002 & 0.008 & $-0.052^{a}$ & 0.018 & -0.005 & 0.012 \\
\hline Extension & $-0.337^{\mathrm{a}}$ & 0.125 & -0.103 & 0.176 & $-0.865^{b}$ & 0.417 & $-0.709^{a}$ & 0.239 \\
\hline Contract farming & -0.119 & 0.143 & -0.016 & 0.208 & -0.698 & 0.669 & -0.203 & 0.258 \\
\hline Training & 0.160 & 0.122 & $0.285^{\mathrm{c}}$ & 0.177 & -0.277 & 0.440 & -0.076 & 0.243 \\
\hline Adults & 0.014 & 0.017 & -0.001 & 0.025 & $-0.275^{a}$ & 0.086 & 0.049 & 0.031 \\
\hline Windstorm & -0.039 & 0.129 & $-0.40^{b}$ & 0.197 & $1.366^{\mathrm{a}}$ & 0.448 & 0.006 & 0.279 \\
\hline Flood & 0.009 & 0.126 & 0.277 & 0.193 & -0.316 & 0.386 & -0.209 & 0.242 \\
\hline Drought & 0.001 & 0.125 & -0.019 & 0.183 & 0.067 & 0.408 & 0.124 & 0.243 \\
\hline $\begin{array}{l}\text { Climate } \\
\text { information }\end{array}$ & -0.001 & 0.117 & -0.194 & 0.178 & 0.046 & 0.366 & 0.335 & 0.221 \\
\hline Forest fires & -0.065 & 0.045 & 0.023 & 0.066 & -0.184 & 0.141 & $-0.207^{\mathbf{b}}$ & 0.093 \\
\hline CCV perception & 0.053 & 0.128 & 0.085 & 0.197 & -0.154 & 0.385 & 0.140 & 0.238 \\
\hline Financial asset & $0.233^{c}$ & 0.127 & -0.042 & 0.185 & 0.571 & 0.447 & $0.618^{\mathbf{b}}$ & 0.263 \\
\hline Physical assets & 0.032 & 0.079 & $0.240^{\mathbf{b}}$ & 0.123 & -0.533 & 0.368 & -0.211 & 0.175 \\
\hline Social assets & -0.002 & 0.011 & 0.026 & 0.017 & $-0.147^{c}$ & 0.082 & -0.023 & 0.019 \\
\hline Human assets & -0.006 & 0.018 & -0.003 & 0.028 & 0.187 & 0.118 & -0.005 & 0.031 \\
\hline $\begin{array}{l}\text { Technological } \\
\text { assets }\end{array}$ & 0.110 & 0.112 & 0.170 & 0.167 & 0.176 & 0.419 & -0.112 & 0.227 \\
\hline Political assets & -0.040 & 0.122 & -0.104 & 0.164 & -0.172 & 0.422 & 0.362 & 0.312 \\
\hline Constant & -0.020 & 0.301 & -0.912 & 0.440 & -1.804 & 1.213 & 0.763 & 0.585 \\
\hline
\end{tabular}

NOTE: ${ }^{\mathrm{a}, \mathrm{b}}$ and ${ }^{\mathrm{c}}$ indicate significant levels at $1 \%, 5 \%$ and $10 \%$, respectively 
Table 7: Factors influencing farmers' crop- agro-processing diversification decision

\begin{tabular}{|c|c|c|c|c|c|c|c|c|}
\hline \multirow[t]{2}{*}{ Variable } & \multicolumn{2}{|l|}{ Pooled } & \multicolumn{2}{|c|}{ Male heads } & \multicolumn{2}{|c|}{ Female heads } & \multicolumn{2}{|c|}{ Female spouses } \\
\hline & Coeff. & Std. Error & Coeff. & Std. Error & Coeff. & Std. Error & Coeff. & Std. Error \\
\hline Gender & -0.153 & 0.132 & & & & & & \\
\hline Age & 0.006 & 0.006 & -0.010 & 0.008 & -0.021 & 0.024 & 0.014 & 0.014 \\
\hline Home keeping & 0.037 & 0.043 & $0.120^{c}$ & 0.071 & $-0.314^{c}$ & 0.164 & -0.131 & 0.084 \\
\hline Experience & -0.004 & 0.005 & 0.011 & 0.008 & 0.009 & 0.019 & $-0.034^{b}$ & 0.014 \\
\hline Extension & $0.360^{\mathrm{a}}$ & 0.126 & 0.264 & 0.178 & $1.076^{\mathbf{b}}$ & 0.440 & 0.383 & 0.243 \\
\hline Contract farming & -0.152 & 0.152 & -0.056 & 0.218 & 0.559 & 0.581 & -0.440 & 0.283 \\
\hline Training & 0.117 & 0.124 & -0.066 & 0.176 & -0.143 & 0.433 & 0.400 & 0.249 \\
\hline Adults & 0.023 & 0.017 & 0.042 & 0.026 & -0.005 & 0.067 & $0.061^{\mathrm{c}}$ & 0.032 \\
\hline Windstorm & 0.015 & 0.131 & 0.183 & 0.186 & -0.394 & 0.419 & -0.058 & 0.306 \\
\hline Flood & -0.179 & 0.131 & -0.244 & 0.196 & 0.026 & 0.482 & 0.073 & 0.261 \\
\hline Drought & $0.358^{\mathrm{a}}$ & 0.130 & $0.339^{\mathrm{c}}$ & 0.182 & 0.267 & 0.430 & 0.422 & 0.268 \\
\hline Climate information & $-0.212^{c}$ & 0.121 & $-0.436^{b}$ & 0.182 & -0.583 & 0.432 & 0.250 & 0.241 \\
\hline Forest fires & $0.077^{\mathrm{c}}$ & 0.047 & 0.092 & 0.067 & $0.301^{\mathbf{c}}$ & 0.157 & -0.044 & 0.104 \\
\hline CCV perception & -0.151 & 0.133 & -0.162 & 0.195 & -0.399 & 0.402 & 0.239 & 0.259 \\
\hline Financial asset & $-0.473^{a}$ & 0.136 & $-0.401^{b}$ & 0.193 & $-1.913^{a}$ & 0.522 & $-0.617^{b}$ & 0.288 \\
\hline Physical assets & 0.070 & 0.081 & -0.058 & 0.120 & $1.413^{\mathrm{a}}$ & 0.395 & -0.262 & 0.211 \\
\hline Social assets & $0.024^{\mathbf{b}}$ & 0.011 & 0.037 & 0.017 & $0.490^{\mathbf{b}}$ & 0.251 & 0.003 & 0.020 \\
\hline Human assets & 0.022 & 0.019 & 0.011 & 0.029 & $0.198^{\mathbf{b}}$ & 0.099 & 0.026 & 0.034 \\
\hline Technological assets & $-0.202^{c}$ & 0.119 & -0.130 & 0.172 & -0.669 & 0.431 & 0.049 & 0.245 \\
\hline Political assets & 0.135 & 0.123 & 0.100 & 0.160 & $1.248^{\mathrm{b}}$ & 0.518 & 0.014 & 0.334 \\
\hline Constant & -1.088 & 0.309 & -0.933 & 0.431 & -0.093 & 1.216 & -0.999 & 0.641 \\
\hline
\end{tabular}

Note: ${ }^{\mathrm{a}, \mathrm{b}}$ and ${ }^{\mathrm{c}}$ indicate significant levels at $1 \%, 5 \%$ and $10 \%$, respectively

Household adults provides an essential labour that are readily available and at a minimum or zero cost. Therefore, households with many adults would have a positive urge to engage in off-farm activities. This was confirmed by the positive significant effect of adults on agro-processing diversification (Tab. 7). This is consistent with the work of Matshe and Young (2004) where households with many household adults had a higher probability of participating in off-farm work and spend longer hours on these activities than those with fewer household adults. In a related study, Ali et al.(2017) found that farmers with larger household sizes have a higher probability of engaging in off-farm activities such as agroprocessing. Experience had a negative effect on agroprocessing diversification on the pooled and female spouses but negative for the male heads and female heads samples. However, this was significant for only the female spouses. Consistently, Ullah et al. (2015) found that, experienced farmers are more likely to avoid diversification in response to climate risks. Contrary, Danso-Abbeam et al.(2017) estimated that farmers with higher experience in maize farming have a higher probability of engaging in off-farm work. Farmers, particularly, female heads that had access to extension services had a higher probability of engaging in off-farm diversification. This was expected as extension services in recent times include agribusiness education such as agroprocessing. Contrary and although not statistically significant, Kassie et al. (2017) found an inverse relationship between agriculture extension and off-farm work engagement.

The climate related factors that significantly influenced the decision to engage in agro-processing are drought, forest fires and access to climate information. For instance, farmers who experienced climate shocks, specifically drought and forest fires in the past three years have a higher probability of engaging in agro-processing than those who did not experience any of these shocks. This is due to the fact that climate shocks farming is highly exposed to the negative impacts of these shocks and the farmers quest for maintaining the standard of living of their families. In recent years, drought has become a major challenge to most of the farmers in northern Ghana, while floods are also affecting lives and properties, especially at the cities. Therefore, farmers may engage in agroprocessing activities as a way of spreading risks from total crop failure due to climate shocks and add value to farm products. It is consistent therefore that household heads (both males and females) that had access to climate information have a lesser probability of engaging in agroprocessing. Thus, with access to climate information on climate shocks and information on the weather, farmers are better placed to make farming decisions and this reduces their probability of engaging in off-farm activities. This is consistent with Mathenge and Tschirley's (2015) noted that rural households engage in off-farm work to offset the effects of weather shocks on farms.

All assets had positive significant effect on diversification into agro-processing except financial and technological assets that were negative. This means that if household's assets are increased, the probability of engaging in agro-processing activities would also increase. This reiterates the important roles assets in shaping the livelihood of households. The negative significant effect of financial asset on agro-processing decision by the farmers can be due to the positive effect of credit on capital mobilization for farm activities and the ability to purchase farm inputs. The negative effect of credit on agro-processing in this study is consistent with 
the findings of Kassie et al. (2017) but contrary to Beyene (2008) who found that credit enhances the probability of engaging in off-farm work. From Aziz et al. (2017), education which involves a measure of human assets have a nonlinear effect on diversification into non-farm activities. Generally, Matshe and Young (2004) found that, assets have a positive effect on the probability of engaging in off-farm work but a negative effect on the hours spent on these activities.

\section{Determinants of crop farmers' diversification into professional and skilled employment}

One of the major forms of livelihood diversification is professional employment and skilled jobs. It is important to note that professional/skilled employment is a form of non-farm activity. In the case of professional jobs such as teaching and health works, farming is considered as a secondary job while farming remained a primary occupation for most farmers with skilled professions such as woodcarving, dressmaking or hairdressing. In this section, the factors that influence farmers' decision to engage in professional or skilled jobs as a response strategy to climate change are discussed (Table 8). The factors that significantly influence diversification into processional/skilled jobs are gender, age, home keeping hours, extension, contract farming, training, climate information, forest fires, climate perception, financial assets, physical assets and technological assets (Tab. 8).

There was a negative significant relationship between professional/skilled employment and gender. This means that female household heads or spouses have a higher probability of engaging in professional activities than the male heads. Although this is contrary to a priori expectations, observations from rural settings of Ghana where this study is conducted suggests that skilled employment is more common among the females than the males. Contrary, Asfaw et al. (2017) however observed that females have less probabilities of engaging in nonfarm works because they engage in household chores that limits their available time for non0farm work.

Age had a negative significant effect on diversification into professional/skilled employment among male household heads and when a pooled sample is assumed. This means that the relatively younger male heads or farmers in general have a higher probability of engaging in skilled and professional activities than the older farmers. This is consistent with the findings of Mathenge and Tschirley (2015). Expectedly, the higher the education of a household, the higher the probability of engaging in skilled or professional employments. Like most other parts of Ghana, persons with higher education would want to engage in white collar and skilled jobs. Ullah et al. (2015) also estimated a positive effect of education on diversification and argued that people become aware of the importance of diversification as a response to climate shocks. In a cross country analysis, Winters et al. (2009) found a positive effect of education on engagement in non-agricultural wage employment in Ghana. Consistently, Mathenge and Tschirley (2015) found that household heads with higher education have a higher probability of engaging in salary employments. The number of hours spent on domestic works had a negative effect on males but positive effect on females. However, the effect is significant for only the females.

Table 8: Determinants of diversification into professional and skilled employment

\begin{tabular}{|c|c|c|c|c|c|c|c|c|}
\hline \multirow[t]{2}{*}{ Variable } & \multicolumn{2}{|l|}{ Pooled } & \multicolumn{2}{|c|}{ Male heads } & \multicolumn{2}{|c|}{ Female heads } & \multicolumn{2}{|c|}{ Female spouses } \\
\hline & Coeff. & Std. Error & Coeff. & Std. Error & Coeff. & Std. Error & Coeff. & Std. Error \\
\hline Gender & $-0.303^{b}$ & 0.135 & & & & & & \\
\hline Age & -0.009 & 0.006 & $-0.029^{a}$ & 0.010 & 0.002 & 0.020 & 0.014 & 0.013 \\
\hline Home keeping & -0.037 & 0.043 & -0.099 & 0.082 & $0.156^{\mathrm{c}}$ & 0.081 & $0.126^{\mathrm{c}}$ & 0.077 \\
\hline Experience & -0.006 & 0.006 & 0.004 & 0.009 & -0.002 & 0.014 & $-0.025^{c}$ & 0.013 \\
\hline Extension & 0.089 & 0.134 & $0.038^{\mathrm{c}}$ & 0.209 & -0.295 & 0.387 & -0.104 & 0.244 \\
\hline Contract farming & $-0.296^{\mathbf{b}}$ & 0.154 & $-0.475^{c}$ & 0.244 & $0.897^{\mathrm{c}}$ & 0.510 & -0.189 & 0.267 \\
\hline Training & $-0.517^{\mathrm{a}}$ & 0.135 & $-0.628^{a}$ & 0.220 & 0.200 & 0.429 & $-0.437^{c}$ & 0.250 \\
\hline Adults & 0.011 & 0.018 & 0.015 & 0.028 & -0.018 & 0.059 & -0.001 & 0.030 \\
\hline Windstorm & -0.170 & 0.136 & -0.321 & 0.219 & -0.014 & 0.339 & 0.071 & 0.284 \\
\hline Flood & 0.082 & 0.134 & -0.010 & 0.221 & -0.132 & 0.346 & 0.135 & 0.241 \\
\hline Drought & -0.031 & 0.130 & 0.187 & 0.202 & 0.316 & 0.415 & -0.327 & 0.246 \\
\hline Climate information & $0.282^{b}$ & 0.124 & $0.620^{\mathrm{a}}$ & 0.204 & 0.314 & 0.383 & -0.233 & 0.222 \\
\hline Forest fires & $-0.129^{a}$ & 0.048 & $-0.183^{b}$ & 0.076 & -0.110 & 0.133 & -0.045 & 0.094 \\
\hline $\mathrm{CCV}$ perception & $0.328^{b}$ & 0.139 & $0.926^{\mathrm{a}}$ & 0.262 & -0.062 & 0.354 & -0.128 & 0.244 \\
\hline Financial asset & $0.222^{\mathrm{c}}$ & 0.136 & 0.198 & 0.208 & 0.202 & 0.370 & -0.009 & 0.274 \\
\hline Physical assets & $0.185^{b}$ & 0.083 & $0.222^{c}$ & 0.130 & $0.337^{\mathrm{c}}$ & 0.198 & 0.256 & 0.179 \\
\hline Social assets & -0.009 & 0.012 & -0.025 & 0.018 & -0.094 & 0.137 & 0.008 & 0.019 \\
\hline Human assets & 0.008 & 0.019 & 0.000 & 0.031 & 0.027 & 0.080 & -0.018 & 0.033 \\
\hline Technological assets & 0.107 & 0.119 & 0.230 & 0.189 & -0.622 & 0.447 & $0.443^{\mathrm{c}}$ & 0.236 \\
\hline Political assets & -0.041 & 0.132 & -0.270 & 0.194 & 0.059 & 0.386 & -0.138 & 0.300 \\
\hline Constant & -0.134 & 0.324 & -0.252 & 0.525 & -1.048 & 1.052 & -0.809 & 0.615 \\
\hline
\end{tabular}

Note: ${ }^{\mathrm{a}, \mathrm{b}}$ and ${ }^{\mathrm{c}}$ indicate significant levels at $1 \%, 5 \%$ and $10 \%$, respectively 


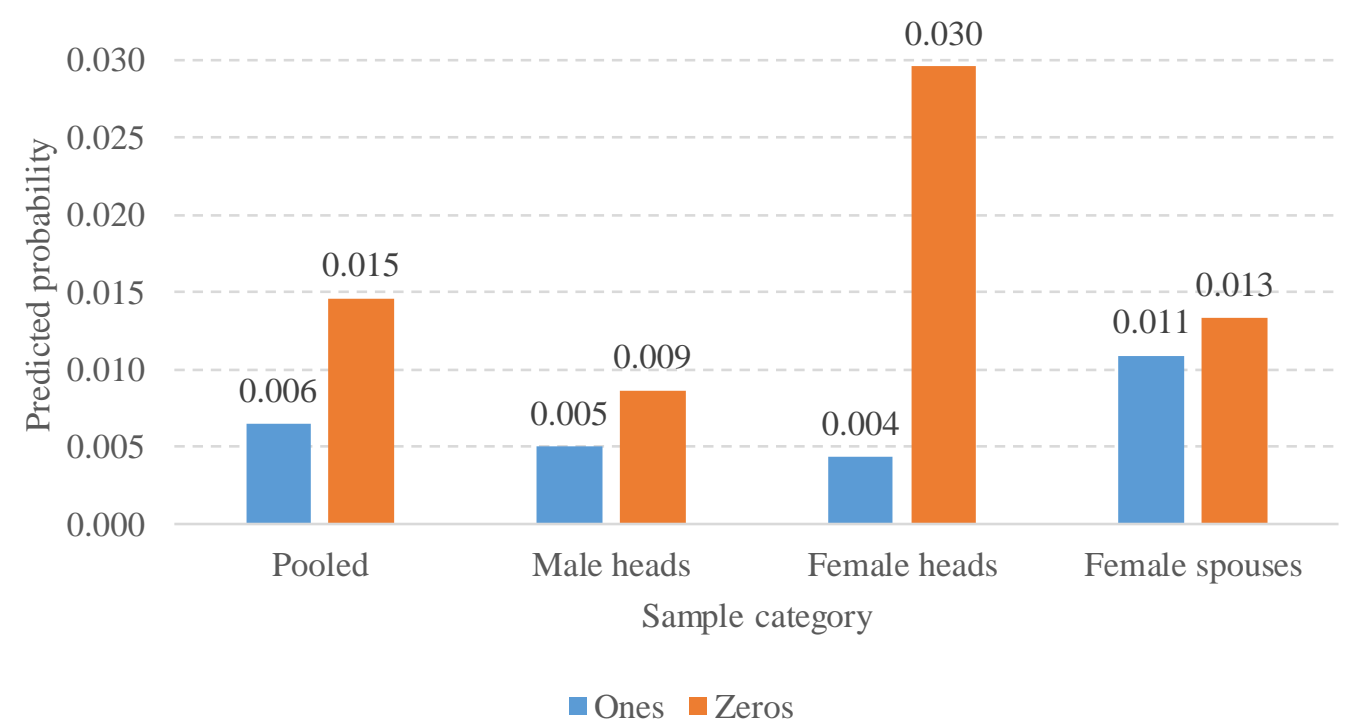

Figure 1: Predicted probability distributions

Source: Computed from multivariate regression results

Although it was expected that domestic hours would reduce available time for economic engagement and diversification, it can be argued that skilled jobs are often performed at home or within the community. Therefore, females may be able to easily combine these skilled jobs with domestic activities than the males. Experience in farming has a negative effect on the decision to engage in skilled and professional activities for all samples except for male heads. However, this effect is significant for only female spouses.

The effect of extension on the decision to engage in skilled and professional employment is positive and significant for only male heads but negative and insignificant for the females. This implied that irrespective of access to extension service by females, their decision on engaging in skilled employment remained significantly unaffected. Asfaw et al. (2017) also estimated that farmers with access to extension services have a higher probability of engaging in skilled employments. There is a negative relationship between contract farming and skilled or professional activities. This relationship is significant for all samples except for female spouses. This means that farmers who engage in contract farming have lesser probabilities of engaging in professional and skilled employments than those who do not engage in contract farming. Contrary to expectations, farmers who had any form of training in crop production have a lesser probability of engaging in skilled or professional activities.

Climate shocks and climate related variables have significant effects on crop farmers' diversification into skilled or professional jobs. These factors include forest fires, climate information and perception on climate change. For instance, there is a negative significant effect of forest fires on the decision of male heads or farmers in general to engage in skilled and professional employments. This is contrary to a priori expectations. Also, farmers, particularly male heads, who had an information on climate change and have perceived changes in climatic conditions appropriately have a higher probability of engaging in skilled and professional jobs. This means that with climate change, farmers are more likely to more away from farm activities to non0farm activities. Contrary, Mathenge and Tschirley (2015) found that households that are located in high rainfall regimes are less likely to engage in salary employments.

Among household asset variables, financial assets, physical asset and technological assets had positive significant effect on diversification into skilled and professional jobs. For instance, financial assets lead to higher probability of engaging in skilled jobs by the farmers in general. The learning of skill or professional activities requires money. Therefore, it is possible that access to agricultural credit relief household income to pay and learn skill and professional activities or that some parts of the credit received are diverted to the learning of these activities. Thus, the real income of the households increases with access to credit, thereby, promoting the learning of skilled or professional jobs. This is consistent to Asfaw et al. (2017) where they estimated a positive effect of access to microfinance on diversification into non-farm employment. Consistently also, Kassie et al. (2017) estimated a positive effect on diversification into non-farm activities. Also, physical assets had significant effect on diversification into skilled jobs by male heads, female heads and farmers in general while technological assets lead to higher probabilities of diversification by female spouses.

\section{Predicted probability distributions}

The predicted joint probabilities of diversification by the respondents (Fig. 1) show that the joint probability of the farmers engaging in none of the livelihood activities is higher $(0.015)$ than the joint probability of engaging in all livelihood activities (0.006). This difference was highly observed among female heads than other category of respondents. The implication is that there is minimal chance for a more diversified livelihood among the 
farmers. However, the female spouses have a higher probability of adopting all diversification portfolios. This is consistent with the estimated negative correlation among the strategies as observed in Table 5

\section{CONCLUSIONS AND RECOMMENDATIONS}

This study examined the factors that influence livelihood diversification among male heads, female spouses and female heads. It involved a multivariate probit model with five equations; crop diversification, animal rearing, trading, agro-processing and professional or skilled employment equations. The estimation of this model was justified by the model diagnosis results. The results highlighted that socioeconomic, climate factors, and household assets have significant influence on each diversification strategy. Depending on the gender group, the effects (either the level of significance or the sign of the marginal effect) of these variables differ. Importantly, climate shocks and access to climate information are important in defining the livelihood diversification strategies of a household. Conclusively, the assumption of gender difference in the factors that influences livelihood diversification is appropriate since some factors which influence specific livelihood diversification for females do not have effect on males. Even in situations where these factors affect both males and females, the direction of the effects differs. There is the need to make climate information available to the farmers on regular basis. Perhaps, this could be done through mobile phones in native languages. Social policies and interventions that can reduce the domestic hours for females should also be promoted. Farmers, government and non-governmental agencies should promote effective social networks and extension service to the farmers since this promote their diversification decisions.

\section{Acknowledgement}

Our sincere appreciation goes to the Federal Ministry of Education and Research (BMBF), Germany, through West African Science Centre on Climate Change and Adapted Land Use (WASCAL) for providing the financial support for this research.

\section{REFERENCES}

ABAY, F., BJØRNSTAD, A. and SMALE, M. (2009). Measuring on Farm Diversity and Determinants of Barley Diversity in Tigray. Momona Ethiopia Journal of Science, 1(2), p. 44-66. DOI: 10.4314/mejs.v1i2.46048.

ADAM, H. and ZAKARIA, H. (2015). Determinants of female labour force participation in farm and non-farm livelihood enterprises: the case of female labour participation in northern Ghana. Journal of Social Science and Humanities, 1(31), p. 239-260.

ALBORE, A. (2018). Review of determinants of sustainable rural livelihood diversification of smallholder farmers in Ethiopia. International Journal of Advanced Research, 6(2), p. 251-259. DOI: 10.21474/IJAR01/6436. ALI, H., SHAFI, M. M. and KHAN, N. P. (2017). Factors affecting off-farm employment of small farmers in
Peshawar Valley. Arts and Social Sciences Journal, 8(2), p. 1-8. DOI: $10.4172 / 2151-6200.1000262$.

ASANTE, B. O., VILLANO, R. A., PATRICK, I. W. and BATTESE, G. E. (2017). Determinants of farm diversification in integrated crop - livestock farming systems in Ghana. Renewable Agriculture and Food Systems, 33(2), p. 131-149. DOI: 10.1017/S1742170516000545.

ASFAW, A., SIMANE, B., HASSEN, A. and BANTIDER, A. (2017). Determinants of non-farm livelihood diversification: evidence from rainfeddependent smallholder farmers in northcentral Ethiopia (Woleka sub-basin). Development Studies Research, 4(1), p. 21-36. DOI: 10.1080/21665095.2017.1413411.

ASMAH, E. E. (2011). Rural livelihood diversification and agricultural household welfare in Ghana. Journal of Development and Agricultural Economics, 3(7), 325-334. ASRAVOR, R. K. (2017). Livelihood diversification strategies to climate change among smallholder farmers in northern Ghana. Journal of International Development. DOI: $10.1002 / \mathrm{jid} .3330$.

AZIZ, S. A., SIDIQUE, S. F. and SAID, R. (2017). Determinants and effects of non-farm enterprise diversification on household economic wellbeing in Rural Nigeria. International Journal of Economics and Management, 11(1), p. 187-204.

BERRANG-FORD, L., FORD, J. D. and PATERSON, J. (2011). Are we adapting to climate change? Global Environnemental Change, 21(1), p. 25-33.DOI: 10.1016/j.gloenvcha.2010.09.012.

BEYENE, A. D. (2008). Determinants of off-farm participation decision of farm households in Ethiopia. Agrekon, 47(1), p. 140-161.

BIRTHAL, P. S., ROY, D. and NEGI, D. S. (2015). Assessing the impact of crop diversification on farm poverty in India. World Development, 72, 70-92. DOI: 10.1016/j.worlddev.2015.02.015.

CHAMBWERA, M., HEAL, G., DUBEUX, C., HALLEGATTE, S., LECLERC, L., MARKANDYA, A., ... and NEUMANN, J. E. (2014). Economics of adaptation. In K. J. M. Field, C.B., V.R. Barros, D.J. Dokken, A. N. L. M.D. Mastrandrea, T.E. Bilir, M. Chatterjee, K.L. Ebi, Y.O. Estrada, R.C. Genova, B. Girma, E.S. Kissel and MacCracken, L. L. W. S. Mastrandrea, P.R. (Eds.), Climate Change 2014: Impacts, Adaptation, and Vulnerability. Part A: Global and Sectoral Aspects. Contribution of Working Group II to the Fifth Assessment Report of the Intergovernmental Panel on Climate Change (pp. 945-977). Cambridge University Press, Cambridge, United Kingdom and New York, NY, USA.

CHANDRA, A., MCNAMARA, K. E., DARGUSCH, P., MARIA, A. and DALABAJAN, D. (2017). Gendered vulnerabilities of smallholder farmers to climate change in conflict-prone areas: A case study from Mindanao, Philippines. Journal of Rural Studies, 50, p. 45-59. DOI: 10.1016/j.jrurstud.2016.12.011.

COCHRAN, W. G. (1977). Sampling Techniques (third edit). New York: John Wiley and Sons.

DANSO-ABBEAM, G., ABBAN, B. A. A. and DONKOH, S. A. (2017). Off-farm participation and technical efficiency among smallholder farmers in the 
Northern Region, Ghana. Applied Studies in Agribusiness and Commerce, 11(1-2), p. 35-44. DOI: 10.19041/APSTRACT/2017/1-2/5.

DEBELE, B. N. and DESTA, G. D. (2016). Livelihood diversification: strategies, determinants and challenges for pastoral and agro-pastoral communities of Bale Zone, Ethiopia. International Review of Social Sciences and Humanities, 11(2), p. 37-51.

DOWNING, T. E. (1993). The effects of climate change on agriculture and food security. Renewable Energy, 3(4). DOI: https://doi.org/10.1016/0960-1481(93)90115-W

DUBE, L. and GUVEYA, E. (2016). Factors influencing smallholder crop diversification: a case study of Manicaland and Masvingo Provinces in. International Journal of Regional Development, 3(2), p. 1-25. DOI: 10.5296/ijrd.v3i2.9194.

FAO. (2016a). Diversification strategies and adaptation deficit: Evidence from rural communities. By Solomon Asfaw, Alessandro Palma and Leslie Lipper. ESA (No. 16.02).

FAO. (2016b). The state of food and agriculture: Climate change, agriculture and food security. Rome.

GEBREYESUS, B. (2016). Determinants of livelihood diversification: The case of Kembata Tambaro zone, Sourthern Ethiopia. Journal of Poverty, Investment and Development, 23, p. 1-10.

GIL, J. D. B., GARRETT, R. and BERGER, T. (2016). Determinants of crop-livestock integration in Brazil: Evidence from the household and regional levels. Land Use Policy, 59, p. 557-568. DOI: 10.1016/j.landusepol.2016.09.022.

GREENE, W. H. (2012). Econometric analysis (Seventh ed.). England: Pearson Education Limited.

GSS. (2012). 2010 population and housing census: summary report of final results. Accra.

GSS. (2014). Ghana living standard survey round 6 (GLSS6): Labour force report. Accra.

GSS. (2015). Ghana poverty mapping report. Accra, Ghana.

HERRERO, M., THORNTON, P. K., NOTENBAERT, A. M., WOOD, S., MSANGI, S., FREEMAN, H. A., BOSSIO, D., DIXON, J., PETERS, M., VAN DE STEEG, J., LYNAM, J., PARTHASARATHY RAO, P., MACMILLAN, S., GERARD, B., MCDERMOTT, J., SERÉ, C. and ROSEGRANT, M. (2010). Smart investments in sustainable food production: Revisiting mixed crop-livestock systems. Science, 327, p. 822-825. DOI: $10.1126 /$ science.1183725.

JAVED, S., NADEEM, A. M., RAFIQUE, M. Z. and KAMRAN, M. A. (2015). Determinants of income diversification among rural households of Pakistan. Journal of Economics and Sustainable Development, 6(14), p. 45-50.

JIAO, X., POULIOT, M. and WALELIGN, S. Z. (2017). Livelihood strategies and dynamics in Rural Cambodia. World Development, 97, p. 266-278. DOI: 10.1016/j.worlddev.2017.04.019.

JOST, C., KYAZZE, F., NAAB, J., NEELORMI, S., KINYANGI, J., ZOUGMORE, R. and KRISTJANSON, P. (2015). Understanding gender dimensions of agriculture and climate change in smallholder farming communities. Climate and Development, 8(2), p. 133 144. DOI: $10.1080 / 17565529.2015 .1050978$.

KASSIE, G. W., KIM, S. and FELLIZARJR, F. P. (2017). Determinant factors of livelihood diversification: Evidence from Ethiopia. Cogent Social Sciences, 3, p. 116. DOI: $10.1080 / 23311886.2017 .1369490$.

LEMAIRE, G., FRANZLUEBBERS, A., CÉSAR, P., CARVALHO, D. F. and DEDIEU, B. (2013). Integrated crop-livestock systems: Strategies to achieve synergy between agricultural production and environmental quality. Agriculture, Ecosystems and Environment, 190(1), p. 4-8. DOI: 10.1016/j.agee.2013.08.009.

LIEBIG, M. A., RYSCHAWY, J., KRONBERG, S. L., ARCHER, D. W., SCHOLLJEGERDES, E. J., HENDRICKSON, J. R. and TANAKA, D. L. (2017). Geoderma Integrated crop-livestock system effects on soil N, P, and pH in a semiarid region. Geoderma, 289, p. 178 184. DOI: $10.1016 /$ j.geoderma.2016.11.036.

MATHENGE, M. K. and TSCHIRLEY, D. L. (2015). Off-farm labor market decisions and agricultural shocks among rural households in Kenya. Agricultural Economics, 46(5), p. 603-616. DOI: 10.1111/agec.12157. MATSHE, I. and YOUNG, T. (2004). Off-farm labour allocation decisions in small-scale rural households in Zimbabwe. Agricultural Economics, 30, p. 175-186. DOI: 10.1016/j.agecon.2003.01.001.

MESFIN, W., FUFA, B. and HAJI, J. (2011). Pattern, Trend and Determinants of Crop Diversification: Empirical Evidence from Smallholders in Eastern Ethiopia. Journal of Economics and Sustainable Development, 2(8), p. 78-90.

MoFA. (2013). Agriculture in Ghana: Facts and figures (2012). Ministry of Food and Agriculture, Statistics, Research and Information Directorate (SRID). Accra. Retrieved from http://www.eagriculture.gov.gh/index.php/2014-07-22-14-3946/agric-facts-and-figures-2012.

NEUDERT, R., GOETTER, J. F., ANDRIAMPARANY, J. N. and RAKOTOARISOA, M. (2015). Income diversification, wealth education and well-being in rural south-western Madagascar: Results from the Mahafaly region. Development Southern Africa, 32(6), p. 1-27. DOI: 10.1080/0376835X.2015.1063982.

NGIGI, M. W., MUELLER, U. and BIRNER, R. (2017). Gender differences in climate change adaptation strategies and participation in group-based approaches: an intrahousehold analysis from rural Kenya. Ecological Economics, 138, p. 99-108. DOI: 10.1016/j.ecolecon.2017.03.019.

NHEMACHENA, C., HASSAN, R. and CHAKWIZIRA, J. (2014). Analysis of determinants of farm-level adaptation measures to climate change in Southern Africa. Journal of Development and Agricultural Economics, 6(5), p. 232-241. DOI: 10.5897/JDAE12.0441.

OFOLSHA, M. D. and MANSINGH, J. P. (2015). Determinants of female-headed households' livelihood diversification strategies choice in Ambo District, Ethiopia. Journal of Extension Education, 27(2), 54235430.

OSARFO, D., SENADZA, B. and NKETIAHAMPONS AH, E. (2016). The impact of nonfarm activities on rural farm household income and food security in the 
Upper East and Upper West Regions of Ghana. Theoretical Economic Leters, 6, p. 388-400. DOI: 10.4236/tel.2016.63043.

OWITTI, O. L. (2015). Gender Differences and Relations in Rural Household Livelihoods of Gog District, Anywaa Zone, Gambella Region, South Western Ethiopia. International Journal of Gender and Women's Studies, 3(1), p. 51-79. DOI: 10.15640/ijgws.v3n1p7.

OWUSU, V., ABDULAI, A. and ABDUL-RAHMAN, S. (2011). Non-farm work and food security among farm households in Northern Ghana q. Food Policy, 36(2), 108118. DOI: $10.1016 /$ j.foodpol.2010.09.002.

RAHMAN, S. and AKTER, S. (2014). Determinants of Livelihood Choices: An Empirical Analysis from Rural Bangladesh. Journal of South Asian Development, 9(3), p. 287-308. DOI: 10.1177/0973174114549101.

REHIMA, M., BELAY, K., DAWIT, A. and RASHID, S. (2013). Factors affecting farmers' crops diversification: Evidence from SNNPR, Ethiopia. International Journal of Agricultural Sciences, 3(6), p. 558-565.

RIEDE, J. O., POSADA, R., FINK, A. H. and KASPAR, F. (2016). What's on the 5th IPCC Report for West Africa? In J. A. Yaro and J. Hesselberg (Eds.), Adaptation to Climate Change and Variability in Rural West Africa (pp. 7-24). Springer International Publishing.

RYSCHAWY, J., CHOISIS, N., CHOISIS, J. P. and GIBON, A. (2013). Paths to last in mixed crop - livestock farming lessons from an assessment of farm trajectories of change. Animal, 7(4), p. 673-681. DOI: 10.1017/S1751731112002091.

SHAHBAZ, P., BOZ, I. and HAQ, S. (2017). Determinants of Crop Diversification in Mixed Cropping Zone of Punjab Pakistan. Direct Research Journal of Agriculture and Food Science, 5(11), p. 360-366. DOI: 10.26765/DRJAFS.2017.2257.

SIMTOWE, F. P. (2010). Livelihoods diversification and gender in Malawi. African Journal of Agricultural Research, 5(3), p. 204-216. DOI: 10.5897/AJAR09.386. SOLTANI, A., ANGELSEN, A., EID, T., SAEID, M., NAIENI, N. and SHAMEKHI, T. (2012). Poverty, sustainability, and household livelihood strategies in Zagros, Iran. Ecological Economics, 79, p. 60-70. DOI: 10.1016/j.ecolecon.2012.04.019.

TARAWALI, S., HERRERO, M., DESCHEEMAEKER, K., GRINGS, E. and BLÜMMEL, M. (2011). Pathways for sustainable development of mixed crop livestock systems: Taking a livestock and pro-poor approach. Livestock Science, 139, p. 11-21. DOI: 10.1016/j.livsci.2011.03.003.
TESSEMA, R. A. (2017). Assessment of the implementation of community-led total sanitation, hygiene, and associated factors in Diretiyara district, Eastern Ethiopia. PLOS ONE, 12(4), p. 1-11. DOI: 10.1371/journal.pone.0175233.

THORNTON, P. K. and HERRERO, M. (2015). Adapting to climate change in the mixed crop and livestock farming systems in sub-Saharan Africa. Nature Climate Change, 5(9), p. 830-836. DOI: 10.1038/nclimate2754.

ULLAH, R., JOURDAIN, D., SHIVAKOTI, G. P. and DHAKAL, S. (2015). Managing catastrophic risks in agriculture: Simultaneous adoption of diversification and precautionary savings. International Journal of Disaster Risk Reduction, 12, p. 268-277. DOI: 10.1016/j.ijdrr.2015.02.001.

VALBUENA, D., ERENSTEIN, O., TUI, S. H., ABDOULAYE, T., CLAESSENS, L., DUNCAN, A. J. and WIJK, M. T. VAN. (2012). Field crops research conservation agriculture in mixed crop - livestock systems: Scoping crop residue trade-offs in Sub-Saharan Africa and South Asia. Field Crops Research, 132, p. 175-184. DOI: 10.1016/j.fcr.2012.02.022.

WILBY, R. L. and DESSAI, S. (2010). Robust adaptation to climate change. Weather, 65(7), p. 180-185. DOI: 10.1002/wea.504.

WINTERS, P., BANK, T. W., STATES, U., ZEZZA, A., AZZARRI, C., COVARRUBIAS, K. and QUIN, E. J. (2009). Assets, Activities and Rural Income Generation: Evidence from a multicountry Analysis. World Development, 37(9), p. 1435-1452. DOI: 10.1016/j.worlddev.2009.01.010.

WOSSEN, T., BERGER, T., HAILE, M. G. and TROOST, C. (2017). Impacts of climate variability and food price volatility on household income and food security of farm households in East and West Africa. Agricultural Systems, 163, p. 7-15. DOI: 10.1016/j.agsy.2017.02.006.

ZAKARIA, H., ABUJAJA, A. M., ADAM, H. and YAKUB, W. (2015). Does gender make any difference in livelihoods diversification? Evidence from northern Ghana. International Journal of Agricultural Extension and Rural Development Studies, 1(1), p. 36-51. 